IMEJ: Islamic Management and Empowerment Journal

Volume 1, Number 2, Desember 2019. p. $143-160$

P-ISSN:2685-953X; e-ISSN:2686-0317

DOI: 10.18326/imej.v1i2.143-160

website: http://e-journal.iainsalatiga.ac.id/index.php/imej

\title{
Analisis Bencana Tanah Longsor di Wilayah Jawa Tengah
}

\author{
Rizkyah Isnaini ${ }^{1}$ \\ Universitas Airlangga Surabaya, Indonesia \\ 1rizkyahisnaini@gmail.com
}

\begin{abstract}
Landslides are one of the disasters that often occur in Indonesia. Central Java Province is an area that has the potential to experience landslides due to varied morphological forms such as plateaus and hills. This study aims to analyze the causes, impacts and management of disaster management. This research uses a qualitative method with a descriptive approach. The data is obtained from supporting data such as BNPB, Central Java BPBD, related scientific articles, and media. The results showed that the impact of landslides threatens the sustainability of the community's life and the causes are high rainfall conditions, steep slope topography, erosion-prone soil conditions, land use is important to be considered to prevent and overcome future landslides.
\end{abstract}

Keywords: analysis, landslide disasters

\begin{abstract}
Abstrak
Tanah longsor adalah salah satu bencana yang sering terjadi di Indonesia. Provinsi Jawa Tengah adalah daerah yang berpotensi mengalami tanah longsor karena bentuk morfologis yang bervariasi seperti dataran tinggi dan bukit. Penelitian ini bertujuan untuk menganalisis penyebab, dampak dan pengelolaan penanganan bencana. Penelitian ini menggunakan metode kualitatif dengan pendekatan deskriptif. Adapun data-data diperoleh dari data pendukung seperti halnya dari BNPB, BPBD Jawa Tengah, artikel ilmiah yang terkait, dan media. Hasil penelitian menunjukkan bahwa dampak bencana tanah longsor mengancam keberlanjutan hidup masyarakat dan penyebabnya adalah kondisi curah hujan yang tinggi, topografi lereng yang curam, kondisi tanah yang rawan erosi, penggunaan lahan menjadi penting diperhatikan untuk mencegah dan mengatasi bencana longsor di masa mendatang.
\end{abstract}

Kata Kunci: Analisis, Bencana tanah longsor. 


\section{Pendahuluan}

Indonesia merupakan salah satu negara yang memiliki kerentanan bencana hidrometeorologi, yaitu bencana yang disebabkan karena perubahan iklim dan cuaca (Susanti dkk, 2017: 50). Menurut UU Nomor 24 Tahun 2007, bencana adalah peristiwa atau rangkaian peristiwa yang mengancam dan mengganggu kehidupan dan penghidupan masyarakat yang disebabkan, baik oleh faktor alam dan/atau faktor non alam maupun faktor manusia sehingga mengakibatkan timbulnya korban jiwa manusia, kerusakan lingkungan, kerugian harta benda, dan dampak psikologis. Bencana terjadi karena adanya ancaman dan kerentanan tanpa ada kapasitas masyarakat untuk menanggulanginya. Bencana dapat mengancam semua wilayah di Indonesia baik di wilayah daratan, pegunungan maupun di wilayah pesisir termasuk di Propinsi Jawa Tengah (Hilmi dkk, 2012). Salah satu jenis bencana di Indonesia yang berpotensi merusak lingkungan, merugikan harga benda dan menimbulkan korban jiwa adalah bencana longsor.

Berdasarkan catatan data kejadian bencana dari Badan Nasional Penanggulangan Bencana, longsor termasuk dalam bencana yang mematikan, karena banyak korban meninggal diakibatkan oleh bencana ini. Kajian dari BNPB menyebutkan bahwa 40,9 juta penduduk Indonesia tinggal di daerah rawan longsor (BNPB, 30 April 2019). Dwikorita Karnawati (2001:12) menyebutkan gejala umum terjadinya tanah longsor di suatu wilayah secara nyata dapat dilihat seperti: 1) munculnya retakanretakan di lereng yang sejajar dengan arah tebing ;2) longsor terjadi setelah datangnya hujan; 3) munculnya mata air baru secara tiba-tiba; 4) tebing menjadi rapuh dan kerikil mulai berjatuhan. Penjelasan tandatanda longsor tersebut sebenarnya tidak sulit diketahui oleh masyarakat setempat, sehingga penting kiranya pendidikan mengenal tanda-tanda bencana longsor penting dilakukan sebagai langkah antisipasi untuk mengurangi risiko dampak yang ditimbulkan.

Terjadinya tanah longsor dapat dipicu oleh curah hujan yang tinggi atau adanya gempa bumi. Wilayah Indonesia yang rawan gempa mengakibatkan beberapa wilayah juga rawan tanah longsor. Kemiringan lereng yang tidak ditopang oleh berbagai tumbuhan dengan perakaran kuat mengakibatkan daerah tersebut semakin mudah longsor. Bahaya tanah longsor semakin tinggi bila semakin besar harkat kemiringan 
lereng, pelapukan batuan, struktur perlapisan batuan, dan tekstur tanah menunjukkan tingkat bahaya tanah longsor yang semakin tinggi (Priyono dkk, 2006).

Menurut data BNPB terdapat 918 lokasi rentan longsor yang tersebar di berbagai wilayah, diantaranya Jawa Tengah 327 lokasi, Jawa Barat 276 lokasi, Sumatera Barat 100 lokasi, Sumatera Utara 53 lokasi, Yogyakarta 30 lokasi, Kalimantan Barat 23 lokasi, sisanya tersebar di NTT, Riau, Kalimantan Timur, Bali, dan Jawa Timur (Pranatasari Dyah Susanti, 2017). Adapun Provinsi Jawa Tengah merupakan provinsi yang paling banyak terjadi bencana tanah longsor. Provinsi Jawa Tengah terletak pada koordinat geografis di antara8ㅇ 30' - 5 40' LS dan 108 30' - 111을 30 BT, dengan ketinggian antara 25 sampai dengan 3.296 meter di atas permukaan laut dan memiliki luas wilayah 32.548,20 km persegi, mempunyai 29 kabupaten, 534 kecamatan, serta 854.031.820 Desa/Kelurahan.

Provinsi Jawa Tengah merupakan kawasan yang berpotensi mengalami bencana tanah longsor karena bentuk morfologi yang bervariasi seperti dataran tinggi dan perbukitan. Sebanyak 125 bencana tanah longsor tercatat terjadi di Provinsi Jawa Tengah selama Januari 2019. Kepala Badan Penanggulangan Bencana Daerah (BPBD) Jateng, Sudaryanto, terdapat 24 Kabupaten atau kota yang terjadi bencana longsor antara lain, Cilacap, Banyumas, Purbalingga, Banjarnegara, Kebumen, Purworejo, Karanganyar, Klaten, Kabupaten Magelang, Wonosobo. Kemudian Temanggung, Kabupaten Semarang, Kabupaten Sragen, Pati, Kudus, Jepara, Kendal, Batang, Kabupaten Pekalongan, Kabupaten Tegal, Brebes, Kota Semarang dan Kota Tegal. Tanah longsor yang terjadi di Provinsi Jawa Tengah sejak terhitung tahun 2018 menyebabkan timbulnya korban dan kerusakan. Sebanyak 22 orang hilang tertimbun longsor, 4 Jiwa hilang, 32 luka ringan dan berat, Jumlah pengungsi tercatat 662 KK dan 2804 jiwa, 192 terancam (jawapos.com, 2019).

Bencana longsor di jawa tengah telah merusak lingkungan, merugikan harta benda dan mengancam keberlanjutan hidup masyarakat. Oleh karenanya upaya penanganan bencana longsor oleh pemerintah harus mendapatkan prioritas dan mendesak untuk dilakukan. Kebutuhan rasa aman untuk melanjutkan kehidupan sehari-hari haruslah dipenuhi untuk memperoleh penghidupan yang sejahtera. Upaya penanganan bencana longsor sudah tentu membutuhkan kajian yang mampu 
menghasilkan sebuah solusi pemecahan untuk mencegah dan mengatasinya. Tujuan penelitian ini adalah untuk menganalisis penyebab dan dampak bencana longsor serta bagaimana mengatasinya. Penelitian ini penting dilakukan untuk menjadi salah satu referensi dalam upaya penanganan bencana longor.

\section{Definisi Tanah Longsor}

Tanah longsor merupakan salah satu bencana alam yang banyak menelan korban jiwa. Hal ini terkait dengan aspek tataguna lahan yang tidak sesuai dengan peruntukannya. Misalnya banyak rumah penduduk di daerah rawan tanah longsor di kabupaten kulonprogo, purworejo, kebumen, dan wonosobo yang dibangun pada lereng bawah dari perbukitan yang rawan longsor. (Sudibyakto, 2011: 88-89). Tanah longsor secara sederhana merupakan jenis dari "pergerakan massa" (mass wasting), dimana tanah dan batuan bergerak mengikuti arah lereng dikarenakan pengaruh gaya gravitasi.

Tanah longsor atau gerakan tanah adalah suatu konsekuensi fenomena dinamis alam untuk mencapai kondisi baru akibat gangguan keseimbangan lereng yang terjadi, baik secara alamiah maupun akibat ulah manusia. Tanah longsor akan terjadi pada suatu lereng jika ada keadaan ketidakseimbangan yang menyebabkan terjadinya suatu proses mekanis, mengakibatkan sebagian dari lereng tersebut bergerak mengikuti gaya gravitasi, dan selanjutnya setelah terjadi tanah longsor, lereng akan seimbang atau stabil kembali (Akhirianto dan Naryanto, 2016: 117).

Menurut UN/ISDR (2009) dalam Ikqra (Tesis, 2012) bahaya adalah potensi kehancuran fisik dan aktifitas manusia yang menyebabkan hilangnya nyawa atau terluka, kehancuran harta benda, gangguan sosial dan ekonomi atau degradasi lingkungan. Dalam hal ini bahaya dapat digolongkan menjadi dua, yaitu dalam kondisi yang terpendam (latent) dan aktif. Bahaya latent disebabkan oleh kondisi alam (geologi, hidrometeorologi, dan biologi) sedangkan aktif disebabkan oleh aktifitas manusia (degradasi lingkungan dan teknologi). Dengan demikian, bahaya longsor adalah suatu potensi terjadinya longsor dalam waktu dekat yang dapat menimbulkan bencana.

Tanah longsor dapat menimbulkan kerusakan yang cukup besar. 
Namun bahaya dan risiko terhadap longsor dapat diminimalisir dengan adanya manajemen risiko yang baik, berkelanjutan, dan informasi yang akurat tentang kejadian longsor. Penggunaan pemetaan tingkat kerawanan longsor merupakan salah satu kunci penting untuk mengurangi risiko tersebut, baik untuk pribadi, umum, pemerintah, sampai peneliti (Shahabi dan Hashim 2015).

\section{Faktor Penyebab Tanah Longsor}

Bencana tanah longsor atau gerakan tanah dari tahun ke tahun semakin sering terjadi di Indonesia, khususnya saat musim hujan. Kondisi tektonik yang membentuk morfologi tinggi, patahan, batuan vulkanik yang mudah rapuh serta ditunjang dengan iklim di Indonesia yang berupa tropis basah, menyebabkan potensi tanah longsor menjadi tinggi. Hal ini ditunjang adanya degradasi perubahan tataguna lahan akhir-akhir ini, menyebabkan bencana tanah longsor menjadi semakin meningkat. Kombinasi faktor anthropogenik dan alam sering merupakan penyebab terjadinya longsor yang memakan korban jiwa dan kerugian harta benda. Upaya mitigasi diperlukan untuk meminimalkan dampak bencana longsor (Naryanto, 2017).

Menurut Paimin, Sukresno dan Pramono (2009) tanah longsor terjadi jika dipenuhi 3 (tiga) keadaan, yaitu: (1) lereng cukup curam, (2) terdapat bidang peluncur yang kedap air dibawah permukaan tanah, dan (3) terdapat cukup air dalam tanah di atas lapisan kedap (bidang luncur) sehingga tanah jenuh air. Cruden dan Varnes (1996) menyebutkan bahwa faktor penyebab longsor dibagi menjadi 2 kelompok, yaitu faktor penyebab dan faktor pemicu. Faktor penyebab antara lain kemiringan lereng, jenis batuan dan jenis tanah. Hujan deras, aktivitas seismic seperti erupsi gunung api dan gempa bumi termasuk kedalam faktor pemicu.

Umumnya, kejadian longsor terdapat banyak penyebabnya, namun pemicunya hanya satu. Menurut Shahabi dan Hashim (2015) lereng yang terjal, curah hujan yang tinggi dan tanah yang tidak stabil merupakan faktor utama terjadinya tanah longsor pada wilayah Asia Tenggara yang memiliki iklim topis, terutama wilayah yang berada di pegunungan dan lembah. Forbes dan Broadhead (2011) juga menjelaskan penebangan hutan, perkembangan penduduk serta infrastruktur terus terjadi pada daerah lereng yang memiliki risiko longsor tinggi. Kelebihan air pada 
tanah, adalah penyebab utama ketidakseimbangan lereng, sementara jenuhnya air didalam tanah dan lereng yang curam merupakan faktor yang meningkatkan risiko terjadinya longsor.

Soeters dan Van Westen (1996) mengatakan bahwa ada 5 kelompok dataset yang umum digunakan untuk menilai kerentanan longsor sebagai berikut:

1. Geomorfologi, misalnya data sub-unit geomorfologi dan bentuk lahan,

2. Topografi dan morfologi, misalnya data lapangan seperti kemiringan, aspek, dan kelengkungan lereng,

3. Geologi, misalnya data litologi dan batuan penyusun, Penggunaan lahan, dan

4. Hidrologi, misalnya data drainase, daerah tangkapan air, dan curah hujan.

\section{Pengelolaan Penanganan Bencana}

Bencana merupakan suatu peristiwa atau kejadian di luar kenormalan yang merusak atau menggangu kehidupan manusia sehingga menimbulkan dampak kerugian atau korban yang melebihi kemampuan masyarakat setempat untuk menanggulangi dengan hanya menggunakan sumber daya sendiri (Aurora, 2017). Menurut Ulum (2013) bencana yang terjadi membawa konsekuensi mempengaruhi kehidupan manusia dan atau lingkungannya. Kerentanan terhadap bencana dapat disebabkan oleh kurangnya manajemen bencana yang tepat, dampak lingkungan, atau manusia sendiri. Penanggulangan bencana terhadap dampak yang ditimbulkan tergantung pada kapasitas komunitas dalam mencegah dan mengatasi bencana.

Penanganan bencana longsor membutuhkan peran aktif masyarakat karena mereka adalah pihak yang merasakan dampak sehingga mengetahui solusi pemecahannya. Apabila penanganan bencana tidak melibatkan partisipasi masyarakat, maka masyarakat tidak akan memiliki kesiapan diri untuk menghadapi bahaya bencana. Berdasarkan hasil studi yang dilakukan oleh Ramadhani dan Idajati (2017) di Kawasan Lereng Gunung Lawu, Kabupaten Karanganyar Jawa Tengah bahwa risiko dan bahaya bencana longsor karena kurangnya kewaspadaan dan kesiapan dalam menghadapi bencana, sehingga perlu adanya peran serta masyarakat dalam menjaga lingkungan dan tentunya diperlukan 
kerjasama antara pemerintah dengan masyarakat dalam menanggulangi bencana longsor. Apabila kondisi yang berpotensi dan rawan maka perlu dikaji tingkat risiko bencana longsor sebagai upaya memposisikan masyarakat pada daerah yang bersangkutan pada tingkat risiko yang berbeda (Ramadhani, 2017).

Penanggulangan bencana oleh pemerintah untuk mengurangi resiko dampak bencana alam telah diatur sebagaimana bunyi undangundang nomor 24 tahun 2007 tentang Penganggulangan Bencana telah membawa perubahan paradigma dalam pengelolaan bencana di Indonesia. Dahulu lebih bersifat responsif atau tanggap darurat dalam menangani bencana sekarang diubah menjadi suatu kegiatan bersifat preventif, sehingga risikonya dapat diminimalisir atau biasa disebut mitigasi (Faturahman, 2018).

Upaya penanganan bencana tidak hanya dilakukan pada saat terjadi bencana melainkan penanganan pencegahan dan mengurangi dampak yang ditumbulkan juga penting diperhatikan. Penanganan bencana untuk mencegah dan mengurangi dampak buruk bencana disebut dengan mitigasi. Konsep mitigasi bencana ialah serangkaian upaya untuk mengurangi akibat-akibat yang ditimbulkan oleh adanya bencana dengan melalui pembangunan fisik, penyadaran terhadap masyarakat dan peningkatan kemampuan menghadapi ancaman bencana. Mitigasi bencana merupakan istilah yang menunjuk pada semua kegiatan/ tndakan untuk mengurangi risiko bencana, yang dapat dilakukan sebelum bencana tersebut terjadi. Mitigasi bencana mencakup perencanaan dan pelaksanaan untuk mengurangi risiko bencana serta proses perencanaan untuk respon yang efektif dalam menghadapi bencana. Tindakan pengurangan risiko bencana tersebut bertujuan untuk mengurangi dampak kerugian yang ditimbulkan akibat bencana dengan menghilangkan kerentanan terhadap bencana (Nurjani dkk, 2013).

Bencana longsor merupakan jenis bencana yang beresiko merugikan dan mengancam kehidupan manusia. Upaya mengurangi risiko dan dampaknya perlu mendapatkan prioritas penanganan. Upaya penanganan bencana sudah tentu membutuhkan kajian mendalam tentang daerah yang memiliki kerentanan dalam menghadapi bahaya bencana. Oleh karena itu, perlu ada identifikasi dan pemetaan wilayah potensial longsor untuk mengetahui tingkat kerentanan suatu wilayah terhadap bencana longsor (Arsjad: 2012). Menurut Fina Faizana dkk (2015: 224) berdasarnya hasil penelitiannya di kota semarang untuk 
melihat kerentanan bencana longsor menggunakan penilaian dengan metode SIG. Kelompok komponen kerentanan bencana tanah longsor adalah:

1. Kerentanan Fisik berdasarkan penataan ruang penduduk suatu wilayah membutuhkan pembangunan infrastruktur untuk mempermudah aktivitas sehari-hari.

2. Kerentanan demografi, Sosial dan Budaya Kerentanan ini dipilih karena di setiap wilayah masyarakat akan mengalami dinamika perkembangan sehingga dalam pendudukan akan membentuk komunitas sosial dan budayanya.

3. Kerentanan Ekonomi. kerentanan ini dipilih karena di setiap wilayah memiliki sumber perekonomian masyarakat untuk mencukupi kebutuhan hidup sehari-hari. Perekonomian masyarakat dan sarana prasaranya penting diperhitungkan untuk menjaga keberlanjutan kehidupan masyarakat dalam menghadapi bencana.

4. Kerentanan Lingkungan. Kerentanan ini dipilih karena lingkungan berperan penting untuk menjaga kualitas dan keseimbangan alam. Secara lebih spesifik komponen kerentanan lingkungan untuk mengetahui seberapa luas yang rusak akibat ancaman bencana tanah longsor. Variabel-variabel bisa bermacam-macam yaitu luas lahan hutan, luas lahan sawah, luas lahan rawa, luas lahan kebun, luas lahan padang rumput.

\section{Metode Penelitian}

Studi dalam penelitian ini berada di Provinsi Jawa Tengah yang terkena bencana tanah longsor. Penelitian ini menggunakan metode kualitatif deskriptif. Menurut Lexy J. Moleng (2005) bahwa penelitian deskriptif kualitatif adalah penelitian mendeskripsikan data apa adanya dan menjelaskan data atau kejadian dengan kalimat penjelas secara kualitatif. Dalam pengumpulan data menggunakan data-data seperti hasil penelitian dari BPBD Jawa tengah, BNPB, media, jurnal dan artikel imiyah terkait.

Penelitian ini bertujuan mengetahui penyebab dan dampak terjadinya tanah longsor di Provinsi Jawa Tengah. Hasil penelitian ini memberikan gambaran secara spasial dan melihat dari faktor hidrometeorologi penyebab tanah longsor. Pengelolaan data penelitian 
dengan menggunakan dioverlay untuk melihat daerah mana yang rentan terhadap bahaya longsor. Data yang digunakan penelitian ini adalah topografi/kemiringan lereng, keadaan tanah, penggunaan lahan dan data curah hujan.

\section{Hasil dan Pembahasan}

\section{Faktor Pemicu Terjadinya Bencana Tanah Longsor di Provinsi Jawa Tengah}

\section{Kondisi Curah Hujan}

Data curah hujan harian yang diambil dari Badan Meteorologi, Klimatologi, dan Geofisika (BMKG: 16 Juli 2016) Kabupaten Cilacap pada bulan sepanjang Juli 2016 hingga Februari 2017 di Provinsi Jawa Tengah, didapat bahwa hujan dengan intensitas tinggi terjadi pada bulan September 2016 dan Oktober 2016 dengan curah hujan berada pada angka $717 \mathrm{~mm}$.

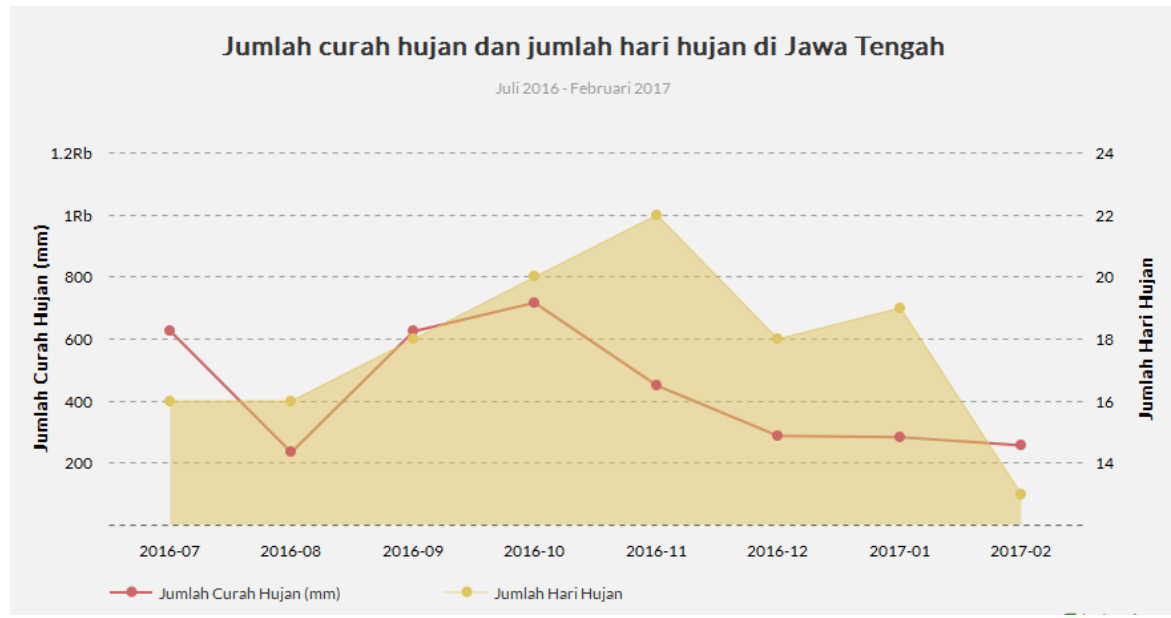

Gambar 1. Timeseries Curah Hujan Provinsi Jawa Tengah

Sumber data: Badan Meteorologi, Klimatologi, dan Geofisika (BMKG) Kabupaten Cilacap

Curah hujan tersebut termasuk kategori tinggi (kategori curah hujan menurut BMKG). Berikut adalah distribusi curah hujan harian di lokasi longsor pada tanggal 01 April 2019. 


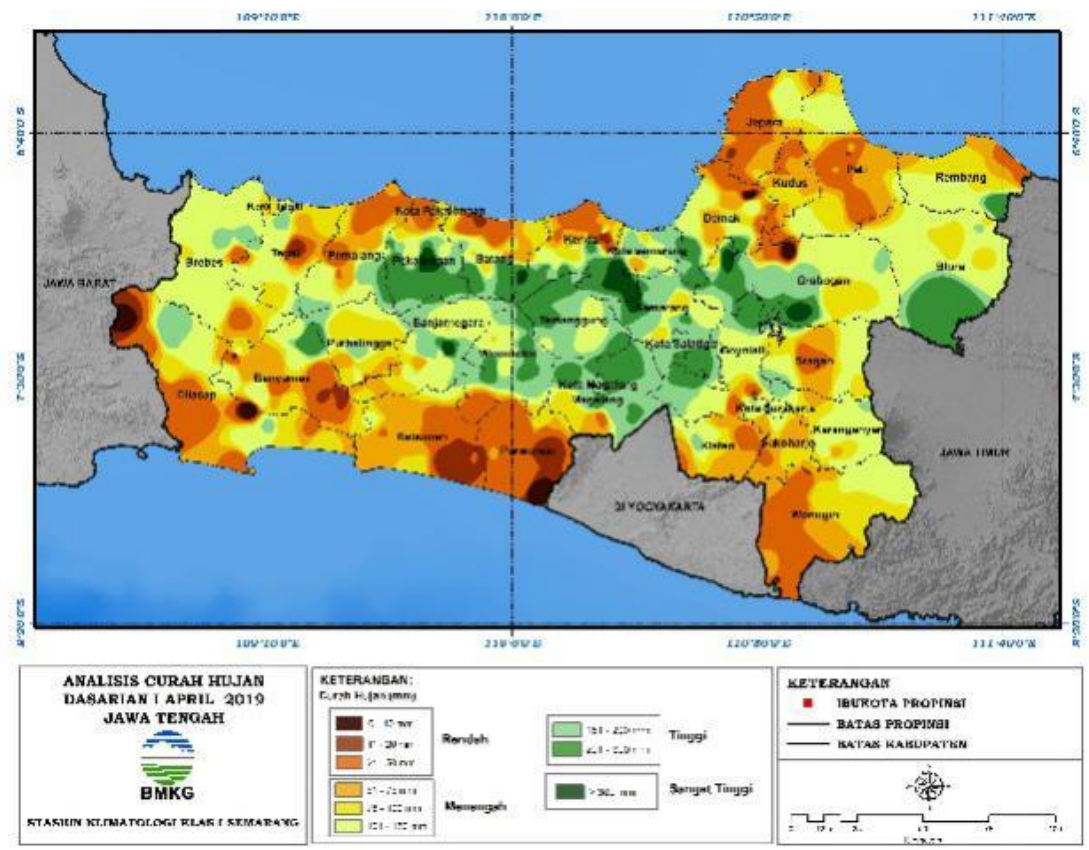

Gambar 2. Distribusi Curah Hujan di Provinsi Jawa Tengah 01 April 2019. Sumber data: Stasiun Klimatologi KabupatenSemarang

Dari gambar 2 tersebut dapat dilihat bahwa curah hujan di Provinsi Jawa Tengah berkisar antara 151-200 mm/hari yang artinya termasuk kategori tinggi.

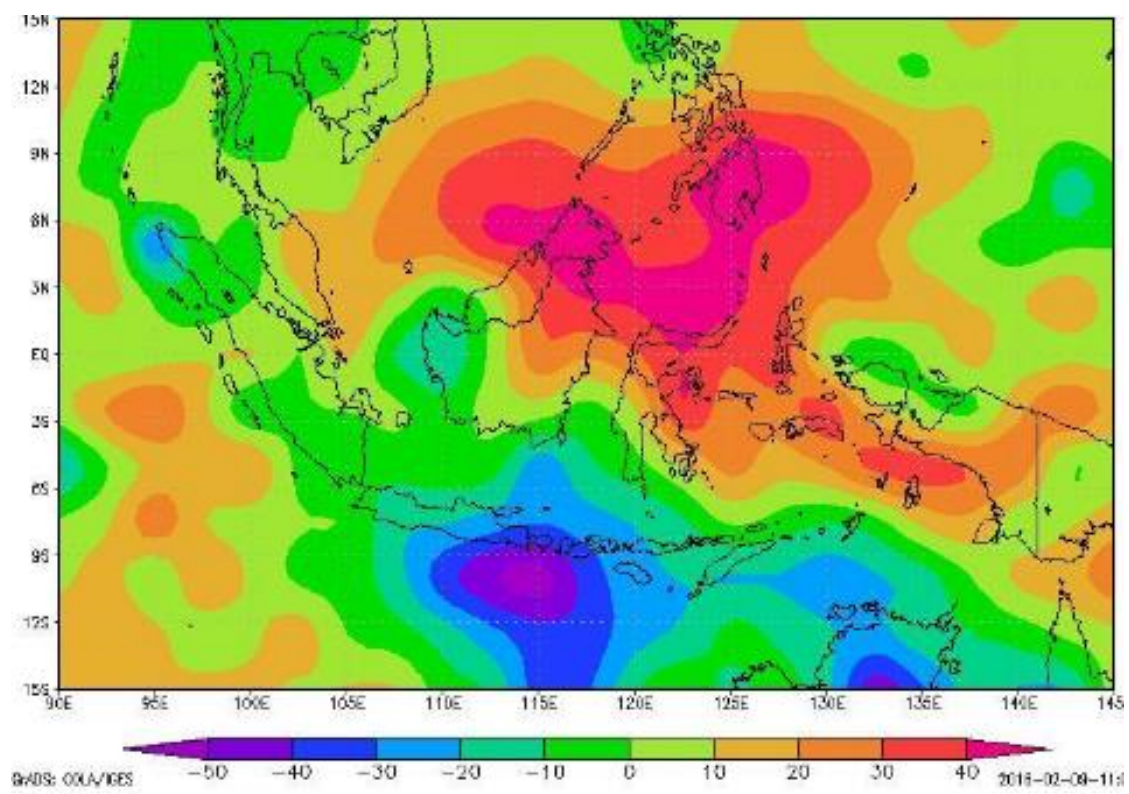

Gambar 3. Anomali Outgoing Longwave Radiation tanggal 25 Januari -3 September 2016 Sumber data: http://www.esrl.noaa.gov

Pada gambar 3 di atas menunjukkan nilai anomali Outgoing 
Longwave Radiation (OLR) pada bulan September 2016 di wilayah Jawa. Tanda kotak merah merupakan wilayah Provinsi Jawa Tengah. Dapat dilihat bahwa nilai anomali OLR di lokasi tersebut berada pada angka -10 s.d $-30 \mathrm{~W} / \mathrm{m} 2$. Nilai anomali bernilai negatif menunjukkan bahwa tutupan awan cenderung lebih tebal dibandingkan dengan normal klimatologisnya. Tutupan awan yang cenderung

Dapat disimpulkan bahwa curah hujan yang terus menerus terjadi di wilayah Ponorogo dapat memicu terjadinya tanah longsor. Curah hujan harian yang terjadi termasuk dalam kategori tinggi. Hasil analisis menunjukkan bahwa hujan yang terus menerus terjadi di wilayah Provinsi Jawa Tengah disebabkan oleh kondisi suhu muka laut yang hangat. Analisis monsoon menunjukkan bahwa indeks monsoon Asia masih cenderung kuat karena pada bulan tersebut wilayah Indonesia sedang berada pada musim peralihan, sehingga curah hujan dengan intensitas sedang - lebat masih mungkin terjadi di Indonesia. Selain itu, adanya daerah bertekanan rendah di wilayah Indonesia bagian selatan juga mendukung pertumbuhan awan yang cukup signifikan di daerah Indonesia bagian barat. menyebabkan hujan sedang - lebat di wilayah Provinsi Jawa Tengah.

\section{Tipografi dan Penggunaan Lahan}

Kondisi topografi wilayah Jawa Tengah beraneka ragam, meliputi daerah pegunu ngan dan dataran tinggi yang membujur sejajar dengan panjang pulau Jawa di bagian tengah; dataran rendah yang hampir tersebar di seluruh Jawa Tengah; dan pantai yaitu pantai Utara dan Selatan. Topografi Provinsi Jawa Tengah memiliki tingkat kemiringan lahan 0-2\% dengan 38\% lahan dari keseluruhan, 31\% lahan memiliki kemiringan 2-15\%, 19\% lahan memiliki kemiringan 15-40\%, dan sisanya 12\% lahan memiliki kemiringan lebih dari 40\%. Ini menunjukkan hanya sedikit lahan yang memiliki kemiringan besar dan dominan pada kemiringan dengan persentase kemiringan yang kecil (BNPB, 2016: 5). 


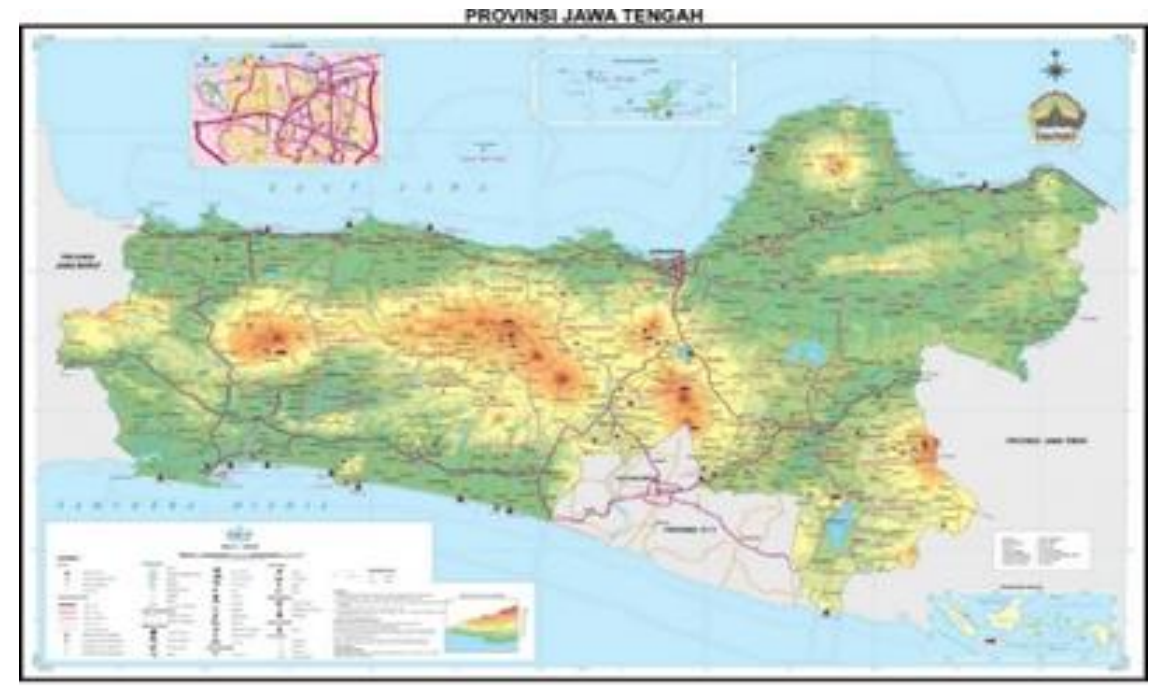

Gambar 4. Topografi atau LerengProvinsi Jawa Tengah Sumber data: https://syuhada.net/peta-jawa-tengah

Menurut Eki Liansyah (2018) Kemiringan lahan dapat menjadi dasar pertimbangan untuk kesesuaian pemanfaatan dan fungsi penggunaan lahan. Topografi Provinsi Jawa Tengah terdiri dari wilayah daratan sebagai berikut:

a. Ketinggian antara 0-100 $\mathrm{m}$ dari permukaan laut yang memanjang di sepanjang pantai utara dan selatan seluas 53,3\%,

b. Ketinggian antara 100-500 $\mathrm{m}$ dari permukaan laut yang memanjang pada bagian tengah pulau seluas $27,4 \%$,

c. Ketinggian 500-1000 m dari permukaan laut seluas 14,7\%,

d. Ketinggian di atas $1000 \mathrm{~m}$ dari permukaan laut seluas 4,6\%

Adapun Penggunaan Lahan di Provinsi Jawa Tengah didominasi oleh lahan pertanian, perkebunan dan area kawasan pemukiman, dalam kawasan. Kondisi penggunaan lahan pada wilayah Provinsi jawa tengah ini di sekitar titik terjadinya tanah longsor banyak ditanami oleh tanaman pertanian dan ditemukannya teras - teras di bagian atas bukit tanpa adanya sistem saluran pembuangan air yang dapat memicu terjadinya longsor. Tanpa adanya sistem pembuangan air, air hujan yang jatuh ke tanah akan tertahan lama di tanah tersebut dan masuk kedalam tanah sehingga tanah tersebut lama kelamaan akan jenuh dan dapat meningkatkan risiko terjadinya tanah longsor. Pada wilayah pertanian, warga memanfaatkan di lereng tersebut untuk menanam tanaman seperti jahe dan jenis - jenis bambu yang tidak memiliki akar yang kuat untuk 
menopang pergerakan tanah, jahe merupakan tanaman semusim yang menyebabkan meningkatnya kapasitas infiltrasi tanah, mempercepat akumulasi air dan kejenuhan tanah (melebihi kemampuan tanah mengikat air).

\section{Potensi Longsor Provinsi Jawa Tengah}

Potensi longsor merupakan hasil overlay antara peta potensi longsor terhadap lereng dan peta potensi longsor terhadap tanah karena sebagai faktor internal. Untuk penggunaan lahan dan curah hujan adalah sebagai faktor eksternal yang akan meningkatkan potensi longsor.

Provinsi Jawa Tengah secara keseluruhan memiliki tingkat potensi longsor rendah hingga agak tinggi. Menurut BPBD Kabupaten yang paling rawan adalah Wonosobo, Banjarnegara, Purbalingga, Purworejo, cilacap, dan Kebumen karena wilayah tersebut di dominasi oleh kemiringan lereng yang miring hingga agak curam dan memiliki jenis tanah Latosol dan Inceptisol yang rentan akan erosi tanah.

Faktor kondisi tanah, kemiringan lereng dan penggunaan lahan menjadi faktor pemicu dalam longsor yang terjadi di Wonosobo, Banjarnegara, Purbalingga, Purworejo, cilacap, dan Kebumen. Perubahan fungsi lahan yang harusnya diperuntukkan untuk tanaman keras menjadi tanaman jahe (empon-empon) telah menyebabkan tidak ada akar tanaman yang menahan tanah. Jahe biasa hidup di tanah dengan ketinggian 200-600 meter di atas permukaan laut dan curah hujan ratarata 2500-4000 mm/tahun (Harris, 1990 dalam Budi, 2009).

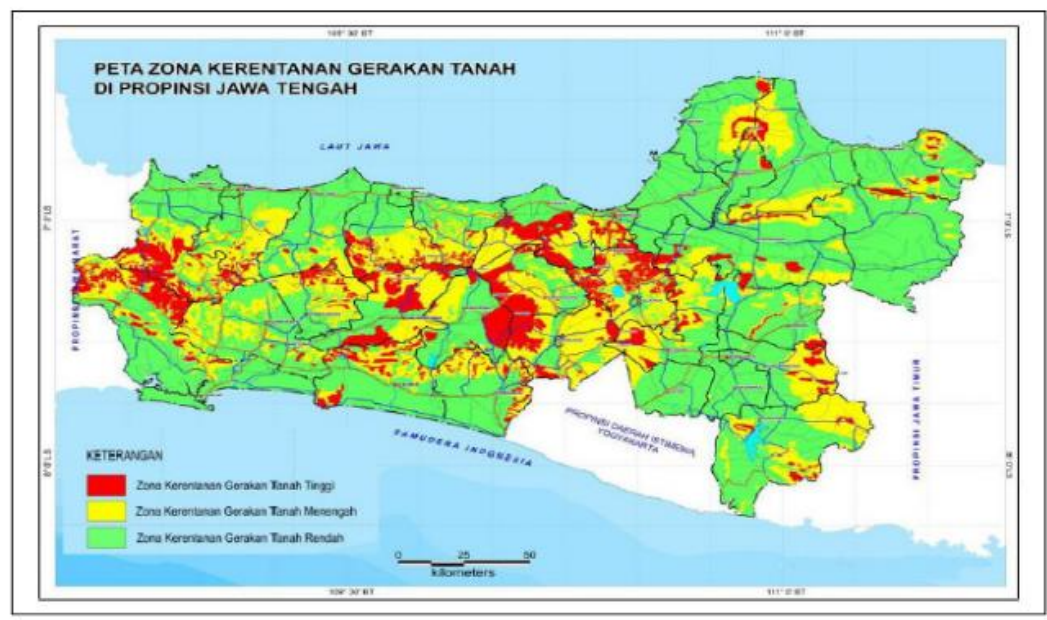

Gambar 8. Potensi Rawan Longsor Jawa Tengah

Sumber data: Badan Penanggulangan Bencana Daerah Jawa Tengah 
Dari penjelasan gambar 8 tersebut tampak bahwa di jalur pantura, daerah yang rawan longsor diantaranya adalah Ketanggungan (Brebes), Kalibening (Pekalongan, jalur alternatif menuju BanjarnegaraYogyakarta), Kendal, Sukorejo (Kendal, jalur alternatif menuju Temanggung- Yogyakarta) dan Gubug (Grobogan). Di Jalur tengah; Ajibarang (Kabupaten Tegal), Kretek (Wonosobo) dan Sumberlawang (Sragen). Sedang di jalur selatan; Lumbir, Wangon, Gumilar (Cilacap) dan Sumpiuh (Banyumas).

\section{Efek Domino dari Bencana Longsor di Provinsi Jawa Tengah}

Bencana tanah longsor sering terjadi di Indonesia dan banyak merenggut korban nyawa maupun harta. Kondisi topografi Indonesia yang banyak terdapat kontur pegunungan, merupakan salah satu faktor utama penyebab terjadinya tanah longsor (Apriyano, 2009: 14). Bencana mampu menimbulkan efek domino, saling mempengaruhi kehidupan, budaya, dam kesehatan masyarakat. Bencana mampu merusak perekonomian masyarakat. Menurut Sutopo (Kepala Pusat Data Informasi dan Humas BNPB) pada tahun 2016 jumlah korban akibat banjir dan longsor di Jawa Tengah adalah 35 orang tewas, 25 orang hilang, 14 orang luka-luka, ratusan rumah rusak dan kerugian ekonomi mencapai miliaran rupiah. Dari jumlah keseluruhan korban jiwa tersebut terdapat di Kabupaten Purworejo 19 tewas, 25 orang hilang, dan 11 luka-luka; di Banjarnegara 6 tewas dan 3 luka-luka; di Kebumen 7 tewas, Sukoharjo 1 tewas, Rembang 1 tewas dan Banyumas 1 tewas. Sebagian besar korban meninggal dan hilang akibat longsor yaitu dari 35 tewas adalah 31 tewas akibat longsor dan 4 tewas akibat hanyut banjir. Untuk memberikan gambaran yang lebih menyeluruh tentang trend bencana longsor yang terjadi di jawa temgah dapat dilihat pada tabel di bawah ini: 
Tabel 1. Kejadian Tanah Longsor Beserta Dampaknya di Jawa Tengah Sumber data: BNPB (http://dibi.bnpb.go.id/)

\begin{tabular}{|c|c|c|c|c|c|c|c|c|c|c|c|}
\hline \multirow[t]{2}{*}{ No } & \multirow{2}{*}{$\begin{array}{c}\text { Wakt } \\
\text { u } \\
\text { Kejad } \\
\text { ian }\end{array}$} & \multirow{2}{*}{$\begin{array}{c}\text { Jumla } \\
\text { h } \\
\text { Kejadi } \\
\text { an }\end{array}$} & \multicolumn{3}{|c|}{ Dampak } & \multicolumn{3}{|c|}{ Rumah (unit) } & \multicolumn{3}{|c|}{ Kerusakan (Unit) } \\
\hline & & & $\begin{array}{c}\text { Menin } \\
\text { ggal }\end{array}$ & $\begin{array}{c}\text { Ruma } \\
\text { h } \\
\text { Rusak }\end{array}$ & $\begin{array}{l}\text { Terda } \\
\text { mpak } \\
\text { Meng } \\
\text { ungsi }\end{array}$ & $\begin{array}{l}\text { Rusa } \\
\text { k } \\
\text { Rusa } \\
\text { k }\end{array}$ & $\begin{array}{c}\text { Rus } \\
\text { ak } \\
\text { Sed } \\
\text { ang }\end{array}$ & $\begin{array}{c}\text { Rusa } \\
\mathbf{k} \\
\text { Ringa } \\
\mathbf{n}\end{array}$ & $\begin{array}{l}\text { Fasili } \\
\text { tas } \\
\text { Kese } \\
\text { hata } \\
\text { n }\end{array}$ & $\begin{array}{c}\text { Fasil } \\
\text { itas } \\
\text { Peri } \\
\text { bad } \\
\text { atan }\end{array}$ & $\begin{array}{c}\text { Fasil } \\
\text { itas } \\
\text { Pen } \\
\text { didi } \\
\text { kan }\end{array}$ \\
\hline 1 & 2013 & 50 & 31 & 18 & 206 & 398 & 27 & 67 & 0 & 0 & 2 \\
\hline 2 & 2014 & 139 & 155 & 45 & 11130 & 112 & 695 & 0 & 0 & 0 & 1 \\
\hline 3 & 2015 & 167 & 13 & 22 & 2782 & 111 & 88 & 268 & 2 & 9 & 8 \\
\hline 4 & 2016 & 250 & 79 & 38 & 4337 & 124 & 317 & 357 & 0 & 1 & 8 \\
\hline 5 & 2017 & 488 & 27 & 48 & 9383 & 369 & 371 & 730 & 1 & 14 & 16 \\
\hline 6 & 2018 & 153 & 28 & 36 & 8606 & 204 & 128 & 257 & 0 & 1 & 1 \\
\hline
\end{tabular}

Dari tabel 1 di atas dapat dikatakan bahwa dampak dari adanya bencana logsor setiap tahun semakin meningkat secara signifikan terlihat perbandingan antara tahun 2016 dan 2017. Menurut Ketua Klimatologi September 2017, BMKG merilis bahwa musim hujan 2017/2018 secara umum akan dimulai pada akhir Oktober - November 2017. Berdasarkan analisis perkembangan musim hujan pada November Dasarian II didapat bahwa sebagian besar wilayah Indonesia sudah mengalami Musim Hujan sebesar $61 \%$ atau sebanyak 209 ZOM sedangkan sebanyak 39\% yaitu 133 ZOM masih mengalami musim kemarau.

\section{Proses Pemulihan Bencana (Recovery) Tanah Longsor di Provinsi Jawa Tengah}

Pada dasarnya upaya penanganan bencana oleh pemerintah tidak hanya dilakukan pada saat terjadi bencana tetapi juga kondisi wilayah setelah bencana mendapatkan perhatian. Dalam Peraturan Daerah Provinsi Jawa Tengah Nomor 1 Tahun 2009 tentang Penyelenggaraan penanggulanagan bencana telah menetapkan kajian dalam rekonstruksi atau pemulihan dal penanganan bencana (Pasal 51): (1) Pembangunan kembali prasarana dan sarana, (2) Untuk mempercepat pembangunan kembali semua prasarana dan sarana serta kelembagaan pada wilayah pascabencana, Pemerintah Daerah menetapkan prioritas dari kegiatan rekonstruksi. (3) Penetapan prioritas pada analisis kerusakan dan kerugian akibat bencana, (4) Dalam menyusun rencana rekonstruksi harus memperhatikan tentang rencana tata ruang; pengaturan mengenai 
standar konstruksi bangunan; kondisi sosial; adat istiadat; budaya lokal; ekonomi.

Namun dalam pelaksanaannya BPBD Provinsi Jawa Tengah kurang efektif dalam melaksanakan tugas tersebut dalam pelaksanaan pemulihan bencana tanah longsor di wilayahnya, hal di atas bias dibuktikan dari banyaknya kerugian yang diperoleh dari kejadian bencana tanah longsor pertahunnya selalu mengalami peningkatan. Walaupun dalam kejadian bencana di tahun 2018 tidak begitu banyak namun kerugian yang dirasakan masih tetap meningkat dari tahun-tahun sebelumnya.

\section{Kesimpulan}

Bencana tanah longsor yang terjadi di wilayah Provinsi Jawa Tengah membuktikan bahwa adanya bahaya dan ancaman kehidupan masyarakat. Dampak bencana yang ditimbulkan telah merusak infrastruktur, merugikan harta benda dan menghilangkan nyawa manusia. Perlindungan masyarakat terhadap bahaya dan ancaman bencana tanah longsor haruslah mendapatkan prioritas dan mendesak untuk dilakukan demi melanjutkan keberlanjutan kehidupan dan kesejahteraan masyarakat.

Mitigasi dan kesiapsiagaan masyarakat yang tinggal di wilayah rawan bencana perlu ditingkatkan untuk mencegah dan mengatasi dampak bencana yang ditimbulkan. Pengetahuan dan kapasitas masyarakat tentang penaganan bencana perlu menjadi perhatian. Semakin masyarakat siap menghadapi bencana, maka risiko dan dampak bencana dapat ditanggulangi dengan baik. Selanjutnya pemerintah penting untuk melibatkan diri secara aktif terutama dalam tahap kesiapsiagaan masyarakat dalam menghadapi bencana longsor.

\section{Daftar Pustaka}

Akhirianto Novian Andri dan Naryanto Sri Heru. Kajian Kapasitas Dan Persepsi Masyarakat Terhadap Bencana Tanah Longsor Di Desa Margamukti, Kecamatan Pangalengan, Kabupaten Bandung. Jurnal Riset Kebencanaan Indonesia Vol. 2 No. 2, Oktober 2016: 117-126 Arwan Apriyono. 2009. Analisis Penyebab Tanah Longsor di Kalitlaga Banjarnegara. Dinamika Rekayasa Vol. 5 No. 1. 
Arsjad M. Suriadi A.B. 2012. Informasi Geospasial Daerah Rawan Longsor Sebagai Bahan Masukan Dalam Perencanaan Tata Ruang Wilayah. Jurnal Globe Volume 14 No. 1: 37 - 45

BNPB. (2016). Data Bencana. Retrieved January 1, 2016, from bnpb.go.id /data-bencana/lihat-data

BNPB. 2015. Dokumen Kajian Risiko Bencana Jawa Tengah 2016-2020. Deputi Bidang Pencegahan dan Kesiapsiagaan

Dwi, Eki Liansyah. 2018. Analisis Kinerja Organisasi Komisi Penyiaran Indonesia Provinsi Jawa Tengah. Semarang: UNDIP.

Faturahman Burhanudin Mukhamad. 2018. Konseptualisasi Mitigasi Bencana Melalui Perspektif Kebijakan Publik Publisia: Jurnal Ilmu Administrasi Publik. Vol. 3, No. 2. 122-134

Fell R, Corominas J, Bonnard C, Cascini L, Leroi E, Savage WZ. 2008. Guidelines for Landslide Susceptibility, Hazard and Risk Zoning for Land-use Planning. Engineering geology.

Fina Faizana dkk. 2015. Pemetaan Risiko Bencana Tanah Longsor Kota Semarang. Jurnal Geodesi Vol. 4, No. 1.

Forbes K, Broadhead J. 2011. Forest and Landslides. Bangkok (TH): FAO. Hilmi, Endang. Hendarto. Eko, Riyanti. Sahri, Asrul. 2012. Analisis Potensi

Bencana Abrasi Dan Tsunami Di Pesisir Cilacap. Jurnal Penanggulangan Bencana Vol. 3 No. 1. 34-42

Ikqra. 2012. Studi Geomorfologi Pulau Ternate dan Penilaian Risiko Longsor [tesis]. Bogor (ID): Institut Pertanian Bogor.

Naryanto, Sri Heru. 2017. Analisis Kejadian Bencana Tanah Longsor Tanggal 12 Desember 2014 Di Dusun Jemblung, Desa Sampang, Kecamatan Karangkobar, Kabupaten Banjarnegara, Provinsi Jawa Tengah. Jurnal Alami, Vol. 1, No. 1.

Neni Yanji Auror. M.D La Ode. Yusnaldi, 2017. Sinergitas Sipil-Militer Untuk Mewujudkan Pemerintahan Yang Baik (Studi Kasus: Pelaksanaan Sinergitas Sipil-Militer Dalam Rangka Pembinaan Desa Tangguh Bencana Di Kecamatan Selupu Rejang Kabupaten Rejang Lebong Provinsi Bengkulu Tahun 2010-2015). Jurnal Dialog Penanggulangan Bencana Vol. 8, No. 2. 151-163.

Nurjani, Emilya. Rahayu, Arum. Rachmawati, Febriyan.2013. Kajian Bencana Angin Ribut Di Indonesia Periode 1990-2011: Upaya Mitigasi Bencana. Geomedia Vol. 11 No. 2.

Moleong, Lexy J.2005. Metode Penelitian Kualitatif. Bandung: Remaja Rosdakarya. 
Paimin, Sukresno dan Pramono, I. B.2009. Teknik Mitigasi Banjir dan Tanah Longsor. Balikpapan: Tropenbos International Indonesia Programme.

Priyono, K, D. Priyana, Y. \& Priyono. 2006. Analisis Tingkat Bahaya Longsor Tanah di Kecamatan Banjarmangu kabupaten Banjarnegara. Surakarta: Universitas Muhammadiyah

Pusat Vulkanologi dan Mitigasi Bencana Geologi, 2013. Gerakan Tanah, Kementrian ESDM, Bandung.

Ramadhani Nuri Iswoyo dan Idajati Hertiati. 2017. Identifikasi Tingkat Bahaya Bencana Longsor, Studi Kasus: Kawasan Lereng Gunung Lawu, Kabupaten Karanganyar, Jawa Tengah. Jurnal Teknik ITS Vol. 6, No. 1.

Shahabi H, Hashim M. 2015. Landslide Susceptibility Mapping Using GISbased Statistical Models and Remote Sensing Data in Tropical Environment. Scientific Reports. Malaysia (MY): Universiti Teknologi Malaysia.

Soeters R, Van Westen CJ. 1996. Slope Stability Recognition, Analysis, and

Zonation Application of Geographical Information System to Landslide Hazard Zonation. [Prosiding]. Di dalam: Landslides: Investigation and Mitigation. Washington DC (US): National Academy Press.

Sudibyakto. 2011. Manajemen Bencana Di Indonesia Ke Mana? Yogyakarta: Gadjah Mada University Press.

Susanti, Pranatasari Dyah. Arina Miardini, Arina dan Harjadi Beny. 2017. Analisis Kerentanan Tanah Longsor Sebagai Dasar Mitigasi di Kabupaten Banjarnegara. Journal of Watershed Management Research. Vol. 1 No. 1: 49-59

Ulum Mochamad Chazienul. 2013. Governance Dan Capacity Building Dalam Manajemen Bencana Banjir Di Indonesia. Jurnal

Penanggulangan Bencana Vol. 4, No. 2. 5-12

https://www.jawapos.com/jpg-today/11/02/2019/januari-2019-125-

bencana-tanah-longsor-terjadi-di-jateng/

https://www.bnpb.go.id/35-tewas-25-hilang-dan-14-luka-luka-akibat-

banjir-dan-longsor-jawa-tengah

https://syuhada.net/peta-jawa-tengah

http://www.bmkg.go.id/

http://dibi.bnpb.go.id/) 